INTERNATIONAL JOURNAL OF RESEARCHES IN BIOSCIENCES, AGRICULTURE AND TECHNOLOGY (c) VISHWASHANTI MULTIPURPOSE SOCIETY (Global Peace Multipurpose Society) R. No. MH-659/13(N) www.ijrbat.in

\title{
ANALYSIS OF BOIL-OFF LOSS IN THE COCOON SHELLS OF THE SILKWORM (BOMBYX MORI L.) BIVOLTINE BREEDS AND THEIR HYBRIDS.
}

\author{
M.N. Anil Kumar \\ Department of Studies in Sericulture Science, University of Mysore, Mysuru-570006, \\ Karnataka, India. \\ Email:anilkumar2068@gmail.com
}

\begin{abstract}
:
The silkworm, Bombyx mori L has been reared since dawn of human civilization because of commercial use of silk in textile industry. The silk fiber is made up of two distinguished proteins namely: fibroin and sericin. The removal of sericin is known as boil off loss ratio (B.O.R). It is considered as one of the important qualitative trait during the course of silk worm breeding. An attempt has been made in the current investigation to record the cocoon parameters and boil off loss ratio in parental bivoltine breeds viz., CSR2, CSR4, CSR6, CSR16, CSR17, CSR26 and CSR27. and direct cross hybrids viz., CSR2 x CSR4, CSR16 x CSR17, CSR2 x CSR27, CSR6 x CSR26 and FC1x FC2 [(CSR6 x CSR26) x (CSR2 x CSR27)] and reciprocal crosses hybrids viz., CSR 4 x CSR2, CSR 17 x CSR16, CSR27 x CSR 2, CSR26 x CSR6 and FC2 $\mathrm{x}$ FC1 [( CSR2 x CSR27) x (CSR6 x CSR26)]. The result of the study inferred that, the hybrids of direct cross performed well in respect of cocoon weight, shell weight, shell percentage, filament length and denier. The hybrids of direct crosses recorded lowest boil-off loss ratio compared to reciprocal crosses. The hybrids of direct crosses such as CSR2 $\mathrm{x}$ CSR4 and CSR16 x CSR17 expressed better heterosis over mid parental value for boil-off loss ratio. Similarly, the hybrid of reciprocal crosses CSR26 x CSR6 expressed heterosis over mid parental value.
\end{abstract}

Keywords: Bivoltine, Biol off- loss ratio, Bombyx mori, direct and reciprocal crosses, heterosis.

\section{INTRODUCTION:}

India has to compete very seriously with sericulturaly advanced country like China in producing quantum and quality of silk. This can be possible only when farmers engaging in the rearing of bivoltine hybrids. Efforts are made by the silkworm breeds to develop high yielding silkworm breeds with specific trait such as boil-off loss ratio. The silkworm Bombyx mori L spins a protective cocoon shell by extruding silk bave at the end of its larval period to protect pupa from adverse environment condition. The silk bave is made up of two principle proteins viz., fibroin and sericin and also contains a little quantity of fat, wax, colouring and mineral matter not exceeding 2-3 \% (Carboni, 1952).

The main silk substance fibroin is insoluble in alkaline hot water, where as gummy protein sericin is easily soluble in boiling alkaline soap solution (Sadov et al, 1978). Without degumming, the silk cannot be called as Queen of Textile. Raw silk neither possesses luster nor softens due to presence of sericin (Roopesh Kumar et al., 2003).
Degumming is the process of removal of sericin. The cocoon shell has more boil-off percentage when compared to the raw silk. The percentage of boil-off loss has got paramount importance in reeling and weaving activities (Kannan, 1986).

In sericulturely advanced countries like China and Japan, silkworm breeders have successfully bred productive hybrids. During the course of breeding, boil off loss is considered as one of the important quantitative traits and for this trait lower value is preferred. The boil-off ratio for bivoltine is found to be $24 \%$ and it is optimum. It is genetically differing among the silkworm strains (Sinha et al., 1992). The degumming loss percentage was higher in multivoltines than bivoltines due to genetic constitution (Sidhu and Sonwalker, 1969). The boil-off loss ratio varies according to the season, which is influenced by the environment (Sonwalker, 1969). The contribution of sericin is highest for mulberry silk (23 to $30 \%$ ) when compared to non-mulberry silk (Venugopal, 1991). Low boil-off ratio content improved cocoon reeling qualities and is manifested by dominant genes, 
while recessive genes act towards the opposite direction (Gamo and Hirabayashi, 1984).

Several reports are available on boil off ratio in silkworm breeds and hybrids. The boil off loss ratio is intermediate in multivoltine $\mathrm{x}$ bivoltine hybrids (Anil Kumar, 2018). Similar trend were also observed in bivoltine hybrids by Basavaraj et al. (2000), Veeranna Gowda et al. (2013) and Seetharamulu et al. (2013).

The silk degumming is necessary for process which make enable the penetration of chemical and dye stuff substances easily. After the removal of sericin the silk is used in weaving process. From the foregoing literature, it is clear that, adequate information is available on boil off loss ratio with respect to silkworm breeds and their hybrids. However, influence of direct and reciprocal crosses in the hybrids of bivoltine is meager. Hence, the present investigation has been under taken.

\section{METHOD AND MATERIAL:}

The disease free layings of parental bivoltine breeds viz., CSR2, CSR4, CSR6, CSR16, CSR17, CSR26, CSR27 procured from NSSO, Mysore. The layings of hybrids viz., CSR2 x CSR4, CSR16 x CSR17, CSR2 x CSR27, CSR6 x CSR26 and FC1 $x$ FC2 (Direct crosses) and reciprocal crosses viz., CSR $4 \times$ CSR2, CSR17 x CSR16, CSR27 x CSR2, CSR26 $\times$ CSR6 and FC2 $\times$ FC1 were prepared. Both parents and hybrids were brushed together and reared by employing standard rearing techniques advocated by Dandin and Giridhar (2010). After the cocoon harvest, ten cocoons (4 replications each) from parental breeds and their hybrids were used to record cocoon parameters such as cocoon weight, shell weight, shell ratio, filament length and denier. In addition to this, degumming of cocoon shell was carried out by boiling the cocoon shells in soap solution as per Basavaraja et al. (2000). The parameters namely, shell ratio, filament length and denier were calculated by using following formulae.

$$
\text { Shell ratio }=\frac{\text { Shell weight }(g)}{\text { Cocoon weight }(g)} \times 100
$$

Filament length $(\mathrm{m}) \quad \mathrm{L}=\mathrm{Rx} 1.125$

Where, $R=$ Number of revolutions of recorded by epprouvette.

$1.125=$ Circumference of epprouvette in meter.

\begin{tabular}{|c|c|}
\hline & $\begin{array}{l}\text { Weight of the } \\
\text { filament }\end{array}$ \\
\hline & $\begin{array}{l}\text { Length of the } \\
\text { filament }\end{array}$ \\
\hline
\end{tabular}

It denotes thickness of the filament.

Degumming

The initial weight of ten cocoon shell of parental breeds and their hybrids of both direct and reciprocal crosses were recorded before degumming process. Further, cocoon shells were subjected to liquor bath consists of mixture of neutral soap and sodium carbonate. The amount of soap and sodium carbonate required for degumming for one gram of cocoon shell are as follows:

$40 \mathrm{ml}$ of liquor solution (Water),

Soap 7 gram per liter,

Soda ash 1 gram per liter.

The cocoon shells of respective breeds and hybrids was immersed in the beaker containing liquor bath where the temperature was maintained at 90 to $95^{\circ} \mathrm{C}$ for about one hour. The material was turned up and down for uniform and effective degumming. Afterwards it was boiled in distilled water for about half an hour. Finally, the material was washed thoroughly in running water and then dried. The final Weight of the material was recorded.

The boil-off loss percentage was calculated by using the formula;

$\begin{array}{ll}\text { B.O.R }= & \begin{array}{l}\text { Initial dry weight }- \text { Final } \\ \text { weight after degumming }\end{array} \\ & \\ \text { Initial dry weight } & \end{array}$


The heterosis for boil-off loss ratio was calculated by using the formula
Heterosis \% (over MPV) =

Heterosis \% (over BPV) =

$$
\frac{\text { F1 - MPV }}{\text { MPV }} \text { X100 }
$$$$
\frac{\text { F1 - BPV }}{\text { BPV }} \times 100
$$

\section{Analysis of data}

The obtained data was compiled and statistically analyzed by employing one-way factorial completely randomized design at 5\% level of significance, OPSTAT online statistical package developed by O.P.Sheoran, Programmer, Computer section Chaudhury Charan Singh Hisar Agriculture University, Hisar, Haryana State, India was used.

\section{RESULTS AND DISCUSSION}

\section{Cocoon weight}

Cocoon weight is an important attribute for the yield as this character mainly depends on the race/breed and its ability to convert mulberry leaf into cocoon. Significant differences were recorded in respect of cocoon weight in parental breeds ranging from 1.598 to $1.745 \mathrm{~g}$ with highest being in CSR17 (1.745g) and lowest in CSR4 (1.598g) (Table 1). The variations in the cocoon weight among parental breeds differing in their genetic constitution for the expression of this trait. The present findings are in conformity with the observations of Anil Kumar (2009), Anantha and Subramanya (2010), Kumaresan et al. (2007) and Rayar et al. (2000).

Among hybrids of direct crosses, FC1 x FC2 recorded highest cocoon weight of $2.162 \mathrm{~g}$ as against to a lowest value of $1.779 \mathrm{~g}$ in CSR6 $\mathrm{X}$ CSR26. Further, hybrids of direct crosses recorded heavier cocoon weight showing their genetic constitution for the expression of this traits. These results are in conformity with the observations of Tazima (1988) who has reported that the hybrids of direct cross recorded heavier cocoon weight.
Among hybrids of reciprocal crosses, FC2 X FC1 registered highest cocoon weight of $2.222 \mathrm{~g}$ and it was lowest in CSR26 X CSR6 (1.647g) (Table 1). Perhaps hybrids might have exhibited significant differences for this traits which is due to varied hybrid vigour. The data pertaining to cocoon weight exhibited lower in reciprocal crosses than those of direct crosses. These results are on par with the findings of Tazima (1988) who has reported that the hybrids of reciprocal crosses of polyvoltine $\mathrm{x}$ bivoltine recorded lower cocoon weight. The cocoon weight is lower in reciprocal crosses may be due to multiple allelism of the maturity genes, which are early maturity (Lme) and late maturity (Lm) genes and these are linked to Z chromosome (Morohshi, 1949).

Shell weight

Shell weight is an important economic character which indicates the silk content. It varies from rearing condition and quality of mulberry leaf. Significantly notable variation was observed in respect of shell weight in parental breeds with highest being in CSR27 (0.401g) as against CSR26 (0.359g) (Table 1). The CSR27 excelled over other breeds for this trait which indicates its genetic superiority. These results are supported by the earlier observations of Anil Kumar (2009). Similar trend was also noticed by Anantha and Subramanya (2010).

Among hybrids of direct crosses, FC1 X FC2 registered maximum shell weight of $0.494 \mathrm{~g}$. In contrast CSR6 X CSR26 recorded a shell weight of 0.399g (Table 1). All the hybrids of direct crosses expressed significant differences with respect to shell weight indicating genetic variations. Further, the direct crosses recorded higher shell weight showing their genetic constitution for the expression of this traits. The present findings are in agreement with the earlier observations of Tazima (1988) who has reported that the hybrids of direct cross recorded higher shell weight. 
Among hybrids of reciprocal crosses, CSR27 $\mathrm{x}$ CSR2 recorded highest shell weight of $0.517 \mathrm{~g}$ and it was lowest in CSR26 x CSR6 (0.358g). In the study, shell weight is lower in reciprocal crosses than those of direct crosses. These results corroborate the earlier findings of Nagmoto (1942) who has opined that heterosis varies in the reciprocal crosses differing in voltinism and maturity period. This is because many qualitative characters are closely associated with the voltinism and maturity period which are known to be sex linked. This was supported by Nakada (1970) and Tazima (1988).

\section{Shell ratio}

Shell percentage is one of the important parameter contributing for silk productivity. These traits also vary significantly different in parental breeds. The highest shell percentage was expressed in CSR27 $(24.57 \%)$ and it was lowest in CSR17 (20.38\%) (Table 1). The variations for this trait within breeds is due to genetic variability for this trait. The present findings are in conformity with the observations of Anil Kumar (2009) and Anantha and Subramanya (2010).

Among hybrids of direct crosses, highest shell percentage was exhibited in CSR2 x CSR4 $(24.29 \%)$ and lowest was recorded in CSR16 $\mathrm{x}$ CSR17 (22.04\%). The hybrids exhibited significant differences for this traits is due to genetic manifestation. The present findings are parallel with earlier observations of Tazima (1988) who have noticed that the hybrids of direct cross recorded higher shell percentage.

The cocoon shell percentage also differ among hybrids of reciprocal crosses with maximum being in CSR27 x CSR2 (24.16\%) as against CSR26 x CSR6 (21.76\%) (Table 1). It is clear from the data that lower shell percentage recorded in reciprocal crosses than those of direct crosses. These results are on par with the observation of Tazima (1988) who has reported that hybrids of reciprocal crosses in polyvoltine $\mathrm{x}$ bivoltine, recorded lower shell percentage. The lower cocoon weight in reciprocal crosses may be due to multiple allelism of the maturity genes.

\section{Filament length}

Filament length is one of the major contributory quantitative traits in silkworm (Miyahara, 1978; Yokoyama 1979). This trait differs significantly among the parental breeds and their hybrids. Among parental breeds, CSR2 expressed maximum filament length of $1092.54 \mathrm{~m}$, whereas CSR6 expressed minimum filament length of $848.29 \mathrm{~m}$ indicating this trait is differing racially. These results are parallel with earlier findings of Anil Kumar (2009) and Anantha and Subramanya (2010).

Among hybrids of direct crosses, longest filament length was registered in CSR16 x CSR17 $(1101.85 \mathrm{~m})$ and it was shortest in CSR6 x CSR26 (960.66m) (Table 1). However, filament length differ significantly among hybrids of direct crosses indicating different genetic makeup of the parents. These results corroborates with earlier observations of Yokoyama (1957), Krishnaswamy et al. (1964), Chang et al. (1981), Gamo and Hirabayashi (1983), Tayade (1987) and Sathenahalli et al. (1989).

The filament length also differs significantly among hybrids of reciprocal crosses with maximum being in CSR4 $x$ CSR2 $(1177.49 \mathrm{~m})$ and minimum in CSR26 x CSR6 (1013.48m) (Table 1).The present findings revealed that, the sex linked genetic factor played a pivotal role on most of the quantity character including filament length where as greater maternal effect was observed on shell weight and filament length in reciprocal crosses.

\section{Denier}

Denier is an important trait identifying silk quality which denotes thickness of the filament. For this trait significant difference observed in parental breeds. Among parental breeds, lowest denier is expressed by CSR26 (2.477) and it was highest in CSR27 (3.003) (Table 1). The variations for this 
trait is due to differing in larval duration within bivoltine breeds. This corroborates with earlier findings of Kalpana et al. (2002) who have reported that shorter the larval duration lesser will be the denier.

The data pertaining denier exhibit significant differences among hybrids of direct and reciprocal crosses. Lowest denier was registered in CSR16 $\mathrm{x}$ CSR17 (2.90) and it was highest in FC1 x FC2 (3.00) (Table 1). The filament size was more in hybrids when compared to its parents. Increase in the thickness of silk filament might be due to positive heterosis and over dominance. These results are parallel with earlier findings of Lakshmi (1996), Kishor Kumar et al. (1997), Rama Mohana Rao et al. (1998) and Premalatha et al. (1997).

It is well documented that in silkworm, all the economic traits are under the control of polygenes expect neatness which is controlled by a semi dominant major gene with few minor genes supporting it. However, the degree of manifestation of the economic traits is governed not only by genotypes but its expression is also depends upon the environment (Nagaraju, 1990).

Boil-off loss percentage

The boil-off ratio is consider one of the important trait along with other quantitative and qualitative traits (Gamo and Ichiba 1971; Harada, 1961; Mano et al., 1988; Yokoyama, 1959). This trait differs significantly among the parental breeds and hybrids.

Among parental breeds lowest boil-off loss was noticed in CSR2 (22.20\%) and CSR4 (22.80\%) and it was highest in CSR27 (24.50 \%) (Fig.1). These results are in agreement with the earlier observations of Sinha et al. (1992) who have reported that the boil-off loss ratio in bivoltine race is found to be $24 \%$ (optimum) and it is genetically differing among the silkworm strains. Moreover the performance of pure lines regarding boil off ratio is more when compared to hybrids (Seetharamulu et al., 2013). Further, degumming loss percentage varies with the breeds / hybrids was also observed by Veeranna Gowda et.al. (2013).

Among hybrids of direct crosses the boil off ratio ranged from 22.10 to $24.75 \%$ with lowest being in CSR2 x CSR4 (22.10\%). Similarly, among hybrids of reciprocal crosses the boil off ratio ranged from $22.59 \%$ to $24.96 \%$ with lowest being in CSR4 x CSR2 (22.59 \%) (Fig.2). In general, boiloff loss ratio was relatively lower in hybrids of direct crosses when compared to hybrids of reciprocal crosses. This clearly indicates the boil off ratio varies in different crossing system. These results are on par with earlier observations of Veeranna Gowda et al., (2013) who have opined that boil-off ratio was relatively lower in hybrids of four way cross (JPN8 x CSR17) x ( DD13 x CSR26) $(22.33 \%)$ when compared to hybrid of three way cross (JPN8 x CSR17) x CSR26 (22.51\%). However, highest value registered for this trait in single cross CSR27 x CSR26 (23.25 \%). Further more, hybrids registered intermediate values for this trait when compared to their parents. These results are corroborate with the earlier findings of Sidhu and Sonwalker (1969), Sinha et al. (1992) and Basavaraja et al. (2000).

Heterosis and over dominance for boil-off loss ratio The phenomenon of heterosis and over dominance in conjunction with the expression of boil-off loss ratio analyzed in the hybrids of direct and reciprocal crosses. Further, the more uniformity in the expression of this trait in hybrids than the parents is one of the desirable features to understand the genetic constitution of the hybrids for their commercial exploitation. For the trait boiloff loss ratio, negative heterosis is desirable. For instance, high magnitude of CSR6 x CSR26 (2.36\%), CSR2 x CSR4 (-1.7\%), CSR 16 x CSR17 ($1.6 \%)$ and CSR26 x CSR6 (-0.4\%). which could be attributed to the higher mid parental values. Similarly, the negative heterosis over better parental value is recorded in CSR2 $x$ CSR4 (-0.4\%) and CSR16 x CSR17 (-0.1\%) (Fig.3). The 
heterosis expressed is variable in different combinations / crosses of hybrids and the results are in accordance with the findings of Gamo and Hirabayashi (1983). More over in hybrids heterosis was intermediate between parents Basavaraja et al. (2000). However, the manifestation of heterosis for this traits differ in direct and reciprocal crosses.

\section{CONCLUSION}

The results of the presents study inferred that, the hybrids of direct crosses CSR2 x CSR4 scored better for the trait boil-off loss ratio. On the other hand, the hybrid CSR6 x CSR26 stood first and expressed heterosis over mid parental value for this trait. This character can be exploited in silk wetting and weaving sector.

\section{REFERANCE :}

Anantha, R. and Subramanya, G. (2010): Differential expression of quantitative traits in multivoltine races and bivoltine breeds of the silkworm, Bombyx mori L. The Bioscan. 5(1): Pp. 35-40.

Anil Kumar, M. N. (2009): Studies on the seasonal variations in protease activity and their correlation with the economic characters in the popular silkworm breeds and their hybrids of Bombyx mori L. Ph. D. Thesis, University of Mysore, Mysore.

Anil Kumar M.N., Jagadisha M.C. and Jayaraju.P. (2018): Quantification of boil- off loss in the cocoon shell of the silkworm (Bombyx mori L.) breeds and their hybrids. International Journal of Research Bioscience, Agriculture and Technology. 1(4): Pp. 74-82.

Basavaraja, H. K., Suresh Kumar, N., Mal Reddy, N. and Datta, R. K. (2000): Studies on the boil-off loss ratio with reference to the cocoon shell in bivoltine silkworm, Bombyx mori L. Indian J. Seric. 31(1): Pp. 60-65.

Carboni, P. (1952): Silk Biology, Chemistry and Technology, Chapman and Hall Ltd. London. Pp.248.

Chang, K.V., Han, B. Y. (1981): Genetic studies on silkworm characters by diallel cross. II. Analysis of heterosis and combining abilities. Seric. J. Korea. 22: Pp.1-7.
Dandin, S. B. and Giridhar, K. (2010): Handbook of Sericulture Technologies, CSB Publications, Bangalore. Pp.427.

Gamo,T. and Ichiba, S. (1971): Selection experiments on the fibroin hybridizing ratio in silkworm cocoons and its effects upon the economical characters. Japan. J. Breed. 21 (2): Pp.87-92.

Gamo, T. and Hirabayshi, T. (1983) Genetic analysis of growth rate, pupation rate and some quantitative characters by diallele crosses in silkworm, Bombyx mori L. Japan J. Breed. 33(2): Pp.178-190.

Gamo, T. and Hirabayashi, T. (1984): Genetic analysis of the boiling-off ratio in cocoon shell by diallele crosses in the silkworm, Bombyx mori L. J. Seric.Sci. Japan. 53(2): Pp.114-120.

Harada, C. (1961): On the heterosis of quantitative characters in silkworm. Bull.Seric. Expt. Stn. 17(1): Pp.50-52.

Kalpana, G. V., Sureshkumar, N., Malreddy, N., Joge, P. G. and Patil, A. K. (2002): Productive bivoltine silkworm hybrids of Bombyx mori $\mathrm{L}$. for longer filament length and thin denier. In: Advance in Indian Sericulture Research (Eds. S. B. Dandin and V. P. Gupta). CSRTI, Mysore. Pp. 117-122.

Kannan A.V. (1986): A short degummed test. Indian Silk. 15(12\&1): Pp.37-38.

Kishor Kumar, C.M., Basavaraja, H.K., Nirmal Kumar, S. and Ramesh Babu, M. (1997): Studies on size deviation of single cocoon filament in bivoltine silkworm breeds and hybrids. Current Technology Seminar. 18-19th September, Central Sericulture and Training Institute, Mysore. Abstract. Pp.19.

Krishnaswami, S., Jolly, M.S. and Subba Rao, G. (1964): Diallele analysis in the multivoltine races of the silkworm Bombyx mori $\mathrm{L}$. genotypes. Entamon. 19(5): Pp.19-522.

Kumaresan, P., Sinha, R. K. and Raje Urs, S. (2007): An analysis of genetic variation and divergence in Indian tropical polyvoltine silkworm (Bombyx mori L.) genotypes. Caspian J. Env. Sc. 5(1): Pp.11-17.

Lakshmi (1996): Studies on the post cocoon parameters in the cross breeds with special reference to size deviation in single cocoon filament. M.Sc Dissertation, University of Mysore, Mysuru. 
Mano, Y., Nishimura, M., Kato, M. and Nagayasu, K. (1988): Breeding of an auto sexing silkworm race N140 x C145. Bull. Seric. Expt Stn. 30(5): Pp. 753-785.

Miyaraha, T. (1978): Selection of long filament basic variety MK. Effect of selection in the later generations. Acta Sericol. 160: Pp. 73- 78.

Morohoshi, S. (1949): Developmental mechanism in Bombyx mori. Meibundo, Tokyo.

Nagamoto, T. (1942): On the inheritance of voltinism in silkworm. J.Sericult. Sci. Japan. 13: Pp.114-115.

Nagaraju, J. (1990): Studies on some genetic aspects of quantitative characters in tropical silkworm, Bombyx mori. Ph.D. thesis, University of Mysore, India.

Nakada, T. (1970): Research on the sex linked inheritance of the cocoon weight of reciprocal crossings. J.Fac. Agric.56: Pp.348-358.

Premalatha, V., Raghavendra Rao, D., Rama Mohan Rao, P., Ahsan, M.M. and Datta, R.K. (1997): Studies on the filament size variation in the single cocoon filament in the multi $\mathrm{x}$ bi hybrids of the silkworm, Bombyx mori L. Current Technology Seminar, 18-19th September, Central Sericulture Research and Training Institute, Mysore. Abstract. Pp.23.

Rama Mohan Rao, P., Premalatha, V., Raghavendra Rao D., Somashekar, T.H., Ahsan, M.M. and Datta, R.K. (1998): Studies on size variation in Bombyx mori L., The Indian Textile Journal.Pp. 72-75.

Rayar, S. G., Kallimani, C. S. and Patil, R. R. (2000): Adaptability of few improved multivoltine breeds of silkworm, Bombyx mori L. across seasons. Silkworm Management in Tropics. Proc. Natl. Sem. Tropic. Seric. (Eds. R. Govindan, K. P. Chinnaswamy, N.K. Krishnaprasad and D. N. R. Reddy). UAS, Bangalore, Pp.37-41.

Sathenahalli, S.B., Govindan, R. and Goud, J.V. (1989): Heterosis studies for some quantitative traits in silkworm, Bombyx mori L. Indian J.Seric. 28: Pp.100-102.

Seetharamulu, J., Seshagiri, S.V. and Raju, P.J. (2013): Boil-off Loss Ratio of Cocoon Shell as a Selection Criterion in the Newly Developed Bivoltine Silkworm (Bombyx mori L.) Hybrids. Int. J. Indust. Entomol. 26(1): Pp.13-21.
Sidhu, N. S. and Sonwalker, T. N. (1969): A preliminary note on the investigation of degumming loss in indigenous, exotic and hybrid cocoons. Silkworm Inf. Bull. 1(1): Pp.39-41.

Sinha, A. K., Sinha, V.S.P., Ghosh, J.K. and Sinha, S.S. (1992): Race differences in cocoon shell of mulberry silkworm, Bombyx mori L. Indian J. Seric. 31(2): Pp.168-176.

Sonwalker, T. N. (1969): Investigation on degumming loss and spinning performance of pierced and cut cocoons in silkworm, B. mori L. Indian J. Seric. 81(1): Pp.43-47.

Roopesh Kumar, K.E., Anathanarayana, S.R. and Nadiger, G.S. (2003): Studies on the effect of spinning conditions of cocoons (Temprature and Relative Humidity) on degumming and dyeing behaviour of selected cross breed and bivoltine hybrid silk filament. Man-Made Textiles in India. 46 (3): Pp.89-99.

Tayade, D.S. (1987): Heterosis effect on economic traits of new hybrids of silkworm, Bombyx mori L. under Marathwada Conditions. Sericologia. 27: Pp.301-307.

Tazima, Y. (1988): A view point on the important of Mysore breeds. Paper presented at International congress for tropical sericulture, Bangalore, India.

Venugopal, B. R. (1991): Degumming of silk, Colourage. 38(3): Pp.48-49.

Veeranna Gowda, Kalpana, G. V., Ashok Kumar, K., Nivedita, S. and Angadi, B.S. (2013): Analysis of the boil-off loss in parental and different crosses of bivoltine silkworm, Bombyx mori L. Entomon, 38(3): Pp. 161-176.

Yokoyama, T. (1957): On the application of heterosis in Japanese sericulture. Proc. Int. Sym. Cytol. Pp. 527-537.

Yokoyama, T. (1959): Silkworm genetics illustrated. Jap. Soc. Prom. Sci. Tokyo, pp 185.

Yokoyama, T. (1979): Silkworm selection and hybridization. In: Genetics in Relation to Insect Management. Working papers, The Rock feller Foundation. Pp. 71-83. 


\begin{tabular}{|c|c|c|c|c|c|c|}
\hline Breed / Hybrids & Cocoon wt (g) & $\begin{array}{l}\text { Shell weight } \\
\text { (g) }\end{array}$ & Shell & $\begin{array}{l}\text { percentage } \\
(\%)\end{array}$ & $\begin{array}{c}\text { Filament length } \\
(\mathrm{m})\end{array}$ & Denier \\
\hline CSR2 & $1.644 \pm 0.003$ & $0.399 \pm 0.003$ & 24.26 & $\begin{array}{l} \pm \quad 0.112 \\
(29.50 \pm 0 . \\
075)\end{array}$ & $1092.54 \pm 26.33$ & $2.863 \pm 0.009$ \\
\hline CSR4 & $1.598 \pm 0.001$ & $0.364 \pm 0.002$ & 22.78 & $\begin{array}{l} \pm \quad 0.084 \\
(28.50 \pm 0 . \\
057)\end{array}$ & $1005.94 \pm 18.06$ & $2.500 \pm 0.010$ \\
\hline CSR6 & $1.720 \pm 0.001$ & $0.395 \pm 0.002$ & $22.98 \pm$ & $\begin{array}{l}0.101 \\
(28.64 \pm 0 \text {. } \\
069)\end{array}$ & $848.29 \pm 1.39$ & $2.923 \pm 0.017$ \\
\hline CSR16 & $1.606 \pm 0.002$ & $0.375 \pm 0.002$ & 23.38 & $\begin{array}{l} \pm \quad 0.099 \\
(28.90 \pm 0 \\
067)\end{array}$ & $1004.47 \pm 22.81$ & $2.567 \pm 0.007$ \\
\hline CSR17 & $1.745 \pm 0.002$ & $0.365 \pm 0.001$ & 20.93 & $\begin{array}{l} \pm \quad 0.063 \\
(27.21 \pm 0 . \\
044)\end{array}$ & $855.35 \pm 26.90$ & $2.970 \pm 0.070$ \\
\hline CSR26 & $1.640 \pm 0.001$ & $0.359 \pm 0.001$ & 21.89 & $\begin{array}{l} \pm \quad 0.015 \\
(27.89 \pm 0 . \\
010)\end{array}$ & $967.84 \pm 12.72$ & $2.477 \pm 0.024$ \\
\hline CSR27 & $1.632 \pm 0.001$ & $0.401 \pm 0.002$ & 24.57 & $\begin{array}{l} \pm \quad 0.084 \\
(29.71 \quad \pm \\
0.56)\end{array}$ & $888.36 \pm 10.89$ & $3.003 \pm 0.019$ \\
\hline CSR2 x CSR4 & $2.027 \pm 0.001$ & $0.492 \pm 0.001$ & 24.29 & $\begin{array}{l} \pm \quad 0.058 \\
(29.52 \quad \pm \\
0.39)\end{array}$ & $1081.31 \pm 31.54$ & $3.010 \pm 0.066$ \\
\hline CSR4 x CSR2 & $2.102 \pm 0.002$ & $0.471 \pm 0.001$ & 22.42 & $\begin{array}{l} \pm \quad 0.026 \\
(28.25 \pm 0 \\
018)\end{array}$ & $1177.49 \pm 43.17$ & $2.900 \pm 0.092$ \\
\hline CSR16 x CSR17 & $2.091 \pm 0.001$ & $0.461 \pm 0.001$ & 22.04 & $\begin{array}{l} \pm \quad 0.043 \\
(27.99 \pm 0 \\
\text { 030) }\end{array}$ & $1101.85 \pm 2.67$ & $2.900 \pm 0.066$ \\
\hline CSR17 x CSR16 & $1.985 \pm 0.001$ & $0.447 \pm 0.001$ & 22.53 & $\begin{array}{l} \pm \quad 0.03 \\
(28.33 \pm 0 \\
020)\end{array}$ & $1052.23 \pm 38.06$ & $2.963 \pm 0.052$ \\
\hline CSR2 $\times$ CSR27 & $1.942 \pm 0.002$ & $0.452 \pm 0.001$ & 23.26 & $\begin{array}{l} \pm \quad 0.054 \\
(28.83 \pm 0 \\
\text { 036) }\end{array}$ & $1061.69 \pm 22.63$ & $2.970 \pm 0.056$ \\
\hline CSR2 $7 \times$ CSR2 & $2.139 \pm 0.002$ & $0.517 \pm 0.001$ & 24.16 & $\begin{array}{l} \pm \quad 0.042 \\
(29.43 \pm 0 \\
028)\end{array}$ & $1164.29 \pm 15.75$ & $2.993 \pm 0.047$ \\
\hline CSR6 X CSR26 & $1.779 \pm 0.002$ & $0.399 \pm 0.001$ & $22.41 \pm$ & $\begin{array}{l}0.044 \\
(28.24 \pm 0 \\
030)\end{array}$ & $960.66 \pm 12.37$ & $2.910 \pm 0.021$ \\
\hline CSR26 6 CSR6 & $1.647 \pm 0.001$ & $0.358 \pm 0.001$ & 21.76 & $\begin{array}{l} \pm \quad 0.059 \\
(27.79 \pm 0 \\
041)\end{array}$ & $1013.48 \pm 10.82$ & $2.713 \pm 0.059$ \\
\hline $\mathrm{FC} 1 \times \mathrm{FC} 2$ & $2.162 \pm 0.002$ & $0.494 \pm 0.001$ & $22.85 \pm$ & $\begin{array}{l}0.035 \\
(28.55 \pm 0 . \\
024)\end{array}$ & $1061.15 \pm 21.96$ & $3.007 \pm 0.020$ \\
\hline $\mathrm{FC} 2 \times \mathrm{FC} 1$ & $2.222 \pm 0.002$ & $0.501 \pm 0.001$ & $22.54 \pm$ & $\begin{array}{l}0.05 \\
(28.33 \pm 0 . \\
035)\end{array}$ & $1085.95 \pm 22.03$ & $2.983 \pm 0.057$ \\
\hline F test & * & * & * & & * & * \\
\hline C.D. & 0.005 & 0.004 & 0.127 & & 65.886 & 0.135 \\
\hline $\mathrm{SE}(\mathrm{m}) \pm$ & 0.002 & 0.001 & 0.044 & & 22.826 & 0.047 \\
\hline $\mathrm{SE}(\mathrm{d}) \pm$ & 0.002 & 0.002 & 0.062 & & 32.281 & 0.066 \\
\hline C.V. & 0.158 & 0.606 & 0.267 & & 3.858 & 2.818 \\
\hline
\end{tabular}

Table 1: Cocoon and post- cocoon parameters of parental breeds and hybrids.

Note: ( ): Angular transformed values, * : Significant at $5 \%$ level.

士: Standard error values. 


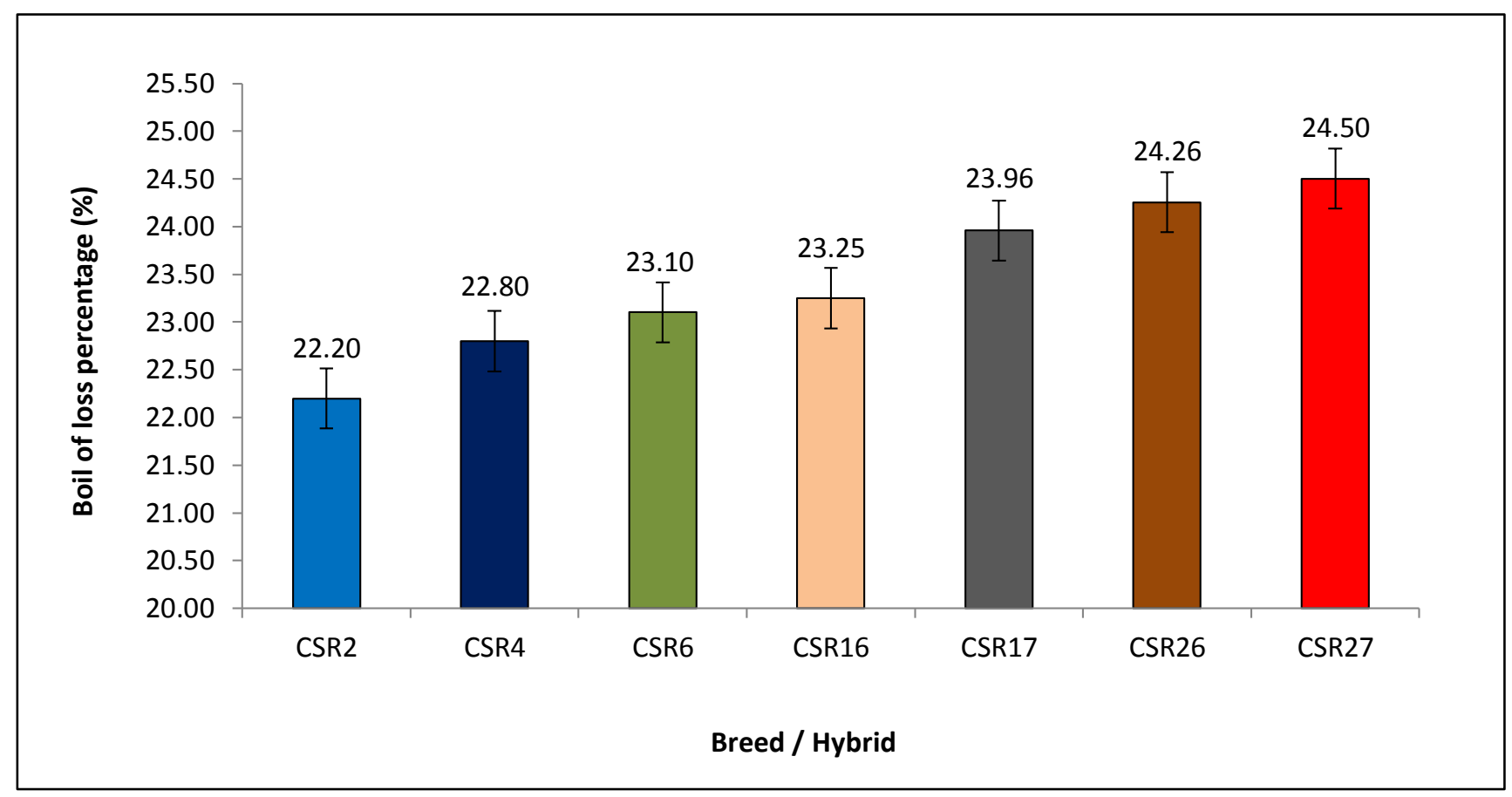

Fig.1: Boil off loss ratio in parental bivoltine breeds.

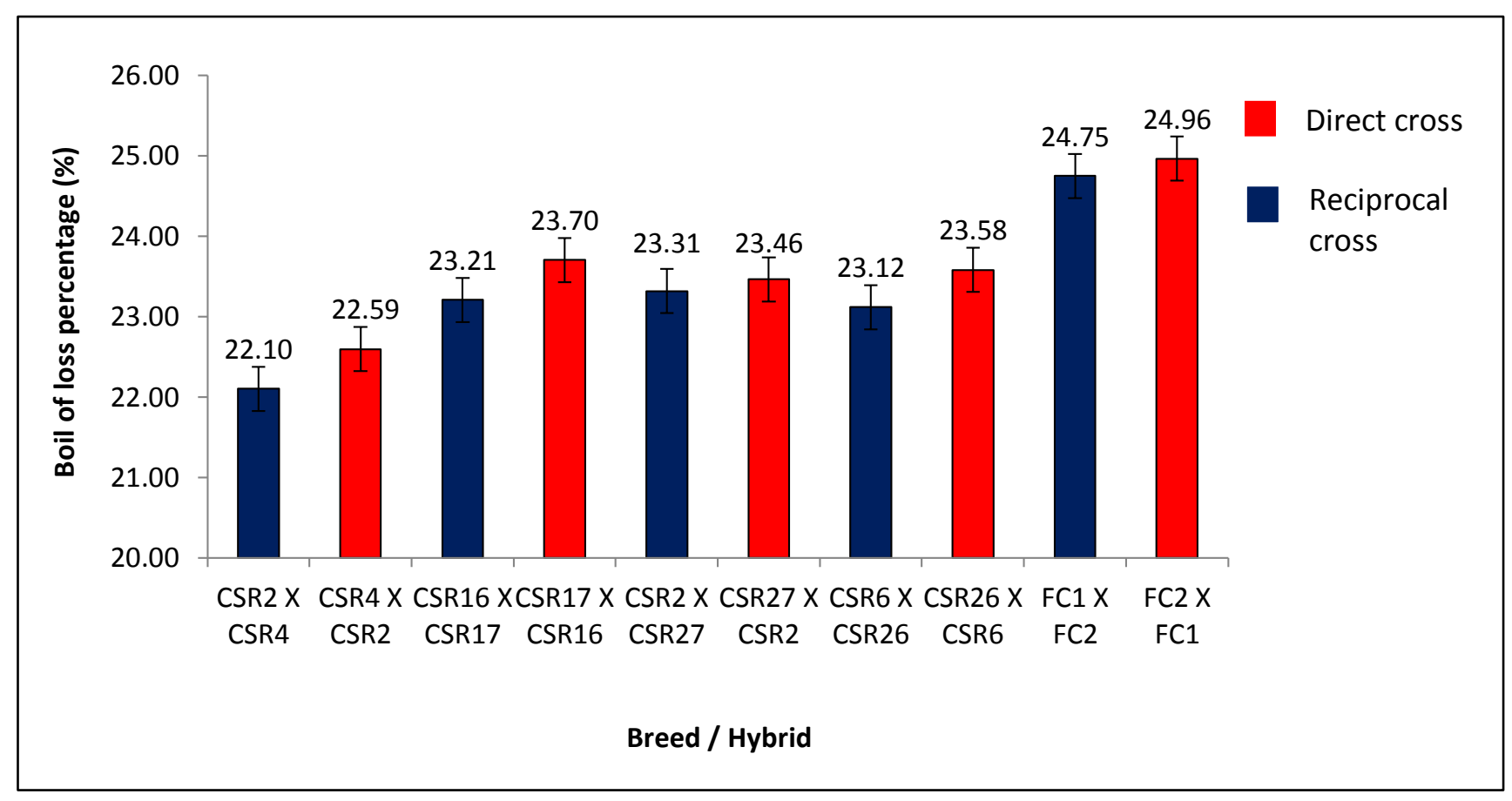

Fig.2: Boil off loss ratio in direct and reciprocal crosses. 


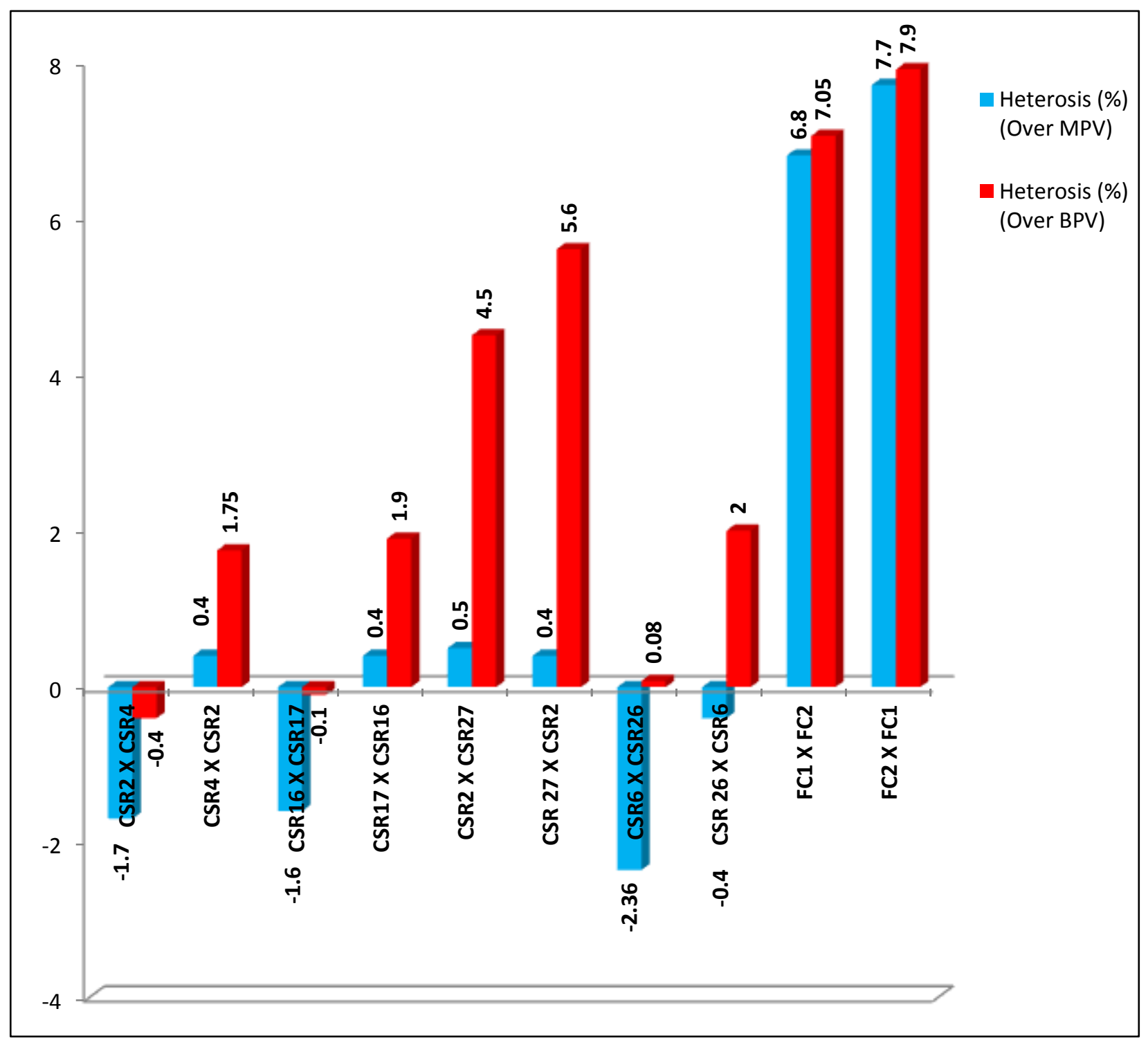

Fig.3: Heterosis over mid parental value (MPV) and better parental value (BPV) for boil-off ratio in bivoltine hybrids. 
